\title{
Maternal death due to COVID-19: is there anything that changed during the treatment? A case report
}

\author{
Pınar Kumru $^{1}$ (D) , Ebru Çöğendez ${ }^{1}$ (D), Eralp Bulutlar ${ }^{1}$ (D), Fırat Ortak ${ }^{1}$ (D), Neslihan Başkılıç² (iD, \\ Tülin Yollu ${ }^{3}$ iD, Resul Karakuş ${ }^{1}$ iD , Semra Kayataş ${ }^{1}$ iD \\ ${ }^{1}$ Department of Obstetrics \& Gynecology, Zeynep Kamil Women and Children Diseases Training and Research Hospital, Health Sciences University, İstanbul, Turkey \\ ${ }^{2}$ Department of Anesthesiology \& Reanimation, Zeynep Kamil Women and Children Diseases Training and Research Hospital, Health Sciences University, Istanbul, Turkey \\ ${ }^{3}$ Department of Anesthesiology \& Reanimation, Üskiidar State Hospital, Istanbul, Turkey
}

\begin{abstract}
Objective: We present a case of maternal death due to COVID-19 and aimed to review our COVID-19 management strategies during pregnancy and changing strategies at different times of the epidemic through the present case.

Case: Our patient was 35 years old, gravida 2, parity 1, 28 weeks pregnant, who admitted to the emergency service of our hospital for the first time with the complaints of severe dry cough, respiratory distress, fever, abdominal pain and vomiting, with suspected COVID-19. She was admitted to the delivery room. As the oxygen need increased within hours and the oxygen saturation decreased to $60 \%$, the patient was intubated 21 hours after hospitalization and was admitted to our second level adult intensive care unit. Due to the development of fetal distress 1 hour after intubation, the patient was taken to emergency cesarean section. Four days after the operation, the patient died due to cardiopulmonary arrest in the $3 \mathrm{rd}$ level intensive care unit of the hospital where she was transferred.

Conclusion: This report demonstrates that COVID-19 can be severe in a pregnant woman, that the importance of early diagnosis and treatment, the difficulties of clinical management in case of progression of the disease, and ultimately, the maternal and neonatal consequences can be devastating.
\end{abstract}

Keywords: COVID-19, pregnancy, maternal death.

\section{Introduction}

Since Coronavirus 2019 (COVID-19) infection caused by SARS-CoV-2 was first identified in Wuhan, China's Hubei province in December 2019, the disease has become global with the general increase in the

\section{Özet: COVID-19 nedeniyle maternal ölüm: Tedavi sırasında herhangi bir değişiklik oldu mu? Olgu sunumu}

Amaç: COVID-19 nedeniyle maternal ölüm gerçekleşen olgumuzu, gebelik sırasında COVID-19 yönetimindeki stratejilerimizi ve epideminin farklı dönemlerindeki değişen stratejileri değerlendirmek amaciyla sunmaktayiz.

Olgu: Hastamız 35 yaşında, gravida 2, parite 1 ve gebeliğin 28 . haftasında şiddetli kuru öksürük, respiratuvar distres, ateş, abdominal ağrı ve kusma şikayetleri eşliğinde COVID-19 şüphesiyle hastanemizin acil servisine ilk kez başvurdu. Doğumhaneye alınan hastanın oksijen ihtiyacı saatler içinde arttığından ve oksijen satürasyonu \%60 azaldığından, olgu hastaneye yatışından 21 saat sonra entübe edildi ve ikinci seviye yetişkin yoğun bakım ünitesine yatırıldı. Entübasyondan 1 saat sonra fetal distresin ortaya çıması üzerine hasta acil sezaryene alındı. Hasta, operasyondan dört gün sonra transfer edildiği hastanenin üçüncü seviye yoğum bakım ünitesinde kardiyopulmoner arrest nedeniyle kaybedildi.

Sonuç: Olgumuz, COVID-19'un gebelerde ciddi sonuçları olabileceğini, erken tanı ve tedavinin önemini, hastalığın ilerlemesi durumunda klinik yönetimin güçlüklerini ve son olarak maternal ve neonatal sonuçların yıkıcı olabileceğini göstermektedir.

Anahtar sözcükler: COVID-19, gebelik, maternal ölüm.

number of cases all over the world. ${ }^{[1]}$ Indeed, following these increases in number, the World Health Organization has declared COVID-19 as a pandemic on March 11, 2020..$^{[2]}$ According to the NIH's COVID-19 management guideline, adults with SARS-

Correspondence: Ebru Çöğendez, MD. Department of Obstetrics \& Gynecology, Zeynep Kamil Women and Children Diseases Training and Research Hospital, Health Sciences University, İstanbul, Turkey. e-mail: ebrucogendez@gmail.com / Received: January 19, 2021; Accepted: February 22, 2021 How to cite this article: Kumru P, Çöğendez E, Bulutlar E, Ortak F, Başkılıç N, Yollu T, Karakuş R, Kayataş S. Maternal death due to COVID-19: is there anything that changed during the treatment? A case report. Perinatal Journal 2021;29(2):173-178. doi:10.2399/prn.21.0292002

ORCID ID: P. Kumru 0000-0002-8905-1909; E. Çöğendez 0000-0001-7062-3076; E. Bulutlar 0000-0002-2246-4899;

F. Ortak 0000-0002-4411-3766; N. Başk1lıç 0000-0001-5592-0523; T. Yollu 0000-0002-9280-4932; R. Karakuş 0000-0003-2654-6119;

S. Kayataş 0000-0003-4675-808X 
CoV-2 infection are categorized as asymptomatic or presymptomatic infection, mild illness, moderate illness, severe illness and critical illness in terms of the severity of the disease. ${ }^{[3]}$

During pregnancy, physiological changes such as decreased functional residual volume, elevation of the diaphragm, mucosal edema in the respiratory tract and altered cellular immune system may lead to increased susceptibility to viral infections and adverse consequences. ${ }^{[4]}$

The most recent data from Centers for Disease Control and Prevention (CDC) show that pregnant women with COVID-19 are more likely to be hospitalized, admitted into the intensive care unit, and intubated. ${ }^{[5]}$ However, despite all this information, the lack of sufficient data on the effects of coronavirus infections during pregnancy limits the counseling and treatment of these patients. In this report, we present a 3rd trimester COVID-19 case who had applied to our hospital's obstetrics emergency clinic on 06 April 2020 following the first COVID-19 case in our country on 11 March 2020, and who could not be saved, despite all the interventions.

\section{Case Report}

The patient was; 35 years old, gravida 2, parity 1, living 1 (normal vaginal delivery), 28 weeks pregnant with suspicion of COVID-19, who admitted to our hospital's emergency department for the first time with complaints of severe dry cough, respiratory distress, fever, abdominal pain and vomiting. She was admitted to the maternity ward. There was no chronic illness, allergy, smoking and alcohol habits in her medical history. The patient was a foreign national (Indonesian) and his husband was Turkish. It was learned that the patient entered our country from Indonesia 15 days ago. In the history of her, there were $38^{\circ}$ fever, weakness, cough, respiratory distress, abdominal pain and vomiting complaints. It was learned that she was admitted to a multidisciplinary hospital 15 days ago with these complaints and was hospitalized due to possible COVID-19 pneumonia and pregnancy.

It was learned that the quantitative reverse transcription polymerase chain reaction (qRT-PCR) (BioSpeedy@ COVID-19 RT-qPCR, Istanbul, Turkey) test result of the patient was negative and that thorax computed tomography (CT) was planned for her only due to the high suspicion of COVID-19. It was understood that the patient left the hospital, and refused the thorax CT scan and medical treatment because of the fear of harming her baby.

Upon increasing symptoms, the general condition of the patient, who applied to our hospital's obstetrics emergency service on April 06, 2020, was moderate, conscious, cooperative, blood pressure: $120 / 70 \mathrm{mmHg}$, pulse: 92 beats $/ \mathrm{min}$, fever: $37.5^{\circ}$, respiratory rate: $18 / \mathrm{min}$, saturation $\mathrm{O}_{2}: 93 \%$. There was no rebound or defense in the abdominal examination. The patient did not have diarrhea, loss of smell and taste among the other signs of COVID-19 disease. Bilateral widespread crepitant rales were detected in lung sounds on auscultation. Biometric measurements in ultrasonography performed to evaluate fetal status were compatible with 28 weeks of gestation, fetal cardiac activity was present, breech presentation was present, amniotic fluid index was $12 \mathrm{~cm}$, placenta localization was posterior, and estimated fetal weight was 997 gram. There was no detached area in the placenta. Antepartum fetal electronic heart rate monitoring was performed with nonstress test (NST) for fetal well-being and it was observed to be reassuring. Cervical dilatation, softening and bleeding were not detected in the bimanual examination.

Laboratory test results at the patient's hospitalization are shown in Table 1. PA lung radiography was performed in the pregnant who was scheduled for thoracic CT, when she refused CT. Ground-glass opacities and dense areas of infiltration were observed in the middlelower zones of the left lung on PA chest radiography. Cardiothoracic ratio was observed as increased (Fig. 1).

The patient, who was followed up for vital signs (heart rate, rhythm, respiratory rate, blood pressure, body temperature, sat $\mathrm{O}_{2}$ ), was consulted to the infectious diseases specialist on the same day, together with clinical findings and examination results. After consultation, $5 \mathrm{~L} / \mathrm{min}$ oxygen therapy and medical treatment was initiated with a surgical mask on the nasal oxygen cannula for the patient who was diagnosed with possible COVID-19. Hydroxychloroquine sulfate $400 \mathrm{mg}$ (Plaquenil ${ }^{\circledR}$ ) twice daily p.o., oseltamivir $75 \mathrm{mg}$ (Enfluvir $^{\circledR}$ ) twice daily p.o., azithromycin $500 \mathrm{mg}$ (Azitro ${ }^{\circledR}$ ) once daily p.o. was added to the medication of the patient, along with meropenem $1 \mathrm{~g}$ vial intravenous three times a day, for bacterial infection prophylaxis. 
Maternal death due to COVID-19: is there anything that changed during the treatment?

Table 1. Laboratory tests of the patient.

\begin{tabular}{|c|c|c|c|c|c|c|}
\hline & $6.04 .2020^{1}$ & $7.04 .2020^{2}$ & $7.04 .2020^{3}$ & $07.04 .2020^{4}$ & $11.04 .2020^{5}$ & Reference values \\
\hline $\mathrm{Hg} \mathrm{g} / \mathrm{dL}$ & 10.1 & 9.3 & 9.5 & 9.60 & 8.60 & $11-18$ \\
\hline Hct \% & 31.5 & 28.1 & 31.1 & 30.90 & 28.50 & $32-54$ \\
\hline WBC $10^{3} / \mathrm{mm}^{3}$ & 17.53 & 18.30 & 24.68 & 27.51 & 19.87 & $4-11$ \\
\hline Neutrophil \% & 85.4 & 85.1 & 89.1 & 89.20 & 92.40 & $42-75.2$ \\
\hline Eosinophil \% & 0.00 & 0.80 & 0.80 & 0 & 0.10 & $0-5$ \\
\hline Basophil \% & 0.6 & 0.5 & 0.8 & 0.6 & 0.80 & $0-3$ \\
\hline Lymphocyte \% & 8.3 & 9.0 & 6.5 & 6.70 & 4.30 & $20-51.1$ \\
\hline Monocyte \% & 5.7 & 4.6 & 3.6 & 3.5 & 2.40 & $1.7-9.3$ \\
\hline MCV & 86.6 & 88.4 & 88.5 & 89.80 & 93.60 & 78-99 \\
\hline $\mathrm{MCH}$ & 27.8 & 27.3 & 27.0 & 28.00 & 28.20 & $24-33$ \\
\hline $\mathrm{MCHC}$ & 32.1 & 30.9 & 30.5 & 31.20 & 30.20 & $29-37$ \\
\hline RDW & 14.1 & 14.1 & 14.1 & 14.40 & 15.30 & $9-28$ \\
\hline MPV & 8.4 & 8.6 & 8.6 & 8.5 & 9.30 & $6.4-11$ \\
\hline NLR & 10.33 & 9 & 9 & 13 & 22 & $0.0-3.13$ \\
\hline Platelet $10^{3} / \mathrm{mm}^{3}$ & 348 & 449 & 449.000 & 409.000 & 271.000 & $130-400$ \\
\hline D-dimer $\mu \mathrm{g} / \mathrm{ml}$ & 1.16 & 2.45 & 3.48 & 3.91 & 17.45 & $0-0.5$ \\
\hline Ferritin $\mathrm{ng} / \mathrm{ml}$ & 196.6 & 210 & 218 & 260 & 172 & $4.63-204$ \\
\hline Troponin I ng/ml & 0.09 & 0.102 & 0.160 & 0.247 & 0.086 & $0.0138-0.0175$ \\
\hline Fibrinogen $\mathrm{mg} / \mathrm{dL}$ & 450 & 489 & 477 & 460 & 490 & $>150$ \\
\hline CRP mg/dl & 10.23 & 10.82 & 12.51 & 13.23 & 12.21 & $0-0.5$ \\
\hline Procalcitonin ng/mL & 0.46 & 0.48 & 0.51 & 0.55 & & $<0.05$ \\
\hline Aspartate aminotransferase U/L & 58 & 58 & 48 & 48 & 55 & $0-34$ \\
\hline LDH U/L & 559 & 702 & 673 & 590 & 603 & $90-250$ \\
\hline Blood urea nitrogen $\mathrm{mg} / \mathrm{dL}$ & 3.7 & 4.6 & 3.3 & 3 & 2.6 & $9-23$ \\
\hline Creatinine $\mathrm{mg} / \mathrm{d}$ & 0.7 & 0.65 & 0.64 & 0.6 & 0.63 & $0.5-1.1$ \\
\hline Direct bilirubin mg/dL & 0.37 & 0.35 & 0.37 & 0.39 & 0.42 & $0-0.5$ \\
\hline Total bilirubin mg/dL & 0.5 & 0.52 & 0.5 & 0.55 & 0.69 & $0.2-1.2$ \\
\hline Glucose mg/dL & 98 & 98 & 133 & 148 & 118 & 70-109 \\
\hline Albumin g/dL & 2.96 & 2.34 & 2.48 & 2.82 & 2.95 & $3.5-5.2$ \\
\hline PT sec & 18.20 & 13.50 & 15.4 & 13.7 & 15.2 & $10.0-15.5$ \\
\hline INR & 1.35 & 0.99 & 1.14 & 1.01 & 1.04 & $0.85-1.2$ \\
\hline Prothrombin time \% & 65 & 101.00 & 82 & 98 & 102 & $70-130$ \\
\hline \multicolumn{7}{|l|}{ Arterial blood gas } \\
\hline $\mathrm{pH}$ & 7.35 & 7.26 & 7.21 & 7.13 & 7.02 & $7.35-7.45$ \\
\hline $\mathrm{pCO}_{2} \mathrm{mmHg}$ & 30.60 & 30.50 & 50.5 & 35 & 95 & $35-45$ \\
\hline $\mathrm{pO}_{2} \mathrm{mmHg}$ & 69.5 & 154 & 74.8 & 88 & 48 & $80-100$ \\
\hline $\mathrm{HCO}_{3} \mathrm{mEq} / \mathrm{L}$ & 18.2 & 14.7 & 17.9 & 15.4 & 30.3 & $24 \pm 2$ \\
\hline $\mathrm{sO}_{2} \%$ & 95.3 & 99.5 & 93.2 & 64 & 78 & $97-98$ \\
\hline $\mathrm{FO}_{2} \mathrm{Hb} \%$ & 93.4 & 98 & 91.6 & 94 & 77 & \\
\hline Glucose in arterial blood mg/dL & 111 & 86 & 137 & 116 & 138 & $70-100$ \\
\hline Lactate in arterial blood $\mathrm{mmol} / \mathrm{L}$ & 1.7 & 0.5 & 0.8 & 0.7 & 2 & $1-1.5$ \\
\hline
\end{tabular}

${ }^{1}$ Examinations of the patient on the day of hospitalization; ${ }^{2}$ Post-intubation examinations of the patient; ${ }^{3}$ Post-operative examinations of the patient; ${ }^{4}$ First examinations in 3rd Stage ICU admission; 5Final examinations in the 3rd Stage ICU. 


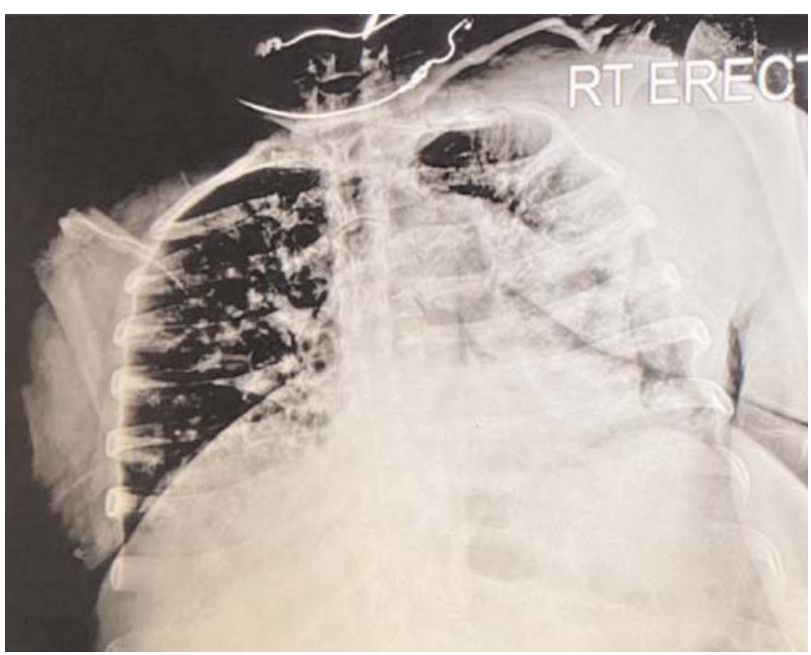

Fig. 1. PA chest radiography of the patient.

Drug selection in medical treatment was made according to our national treatment guideline. The fetus was followed up by continuous electrocardiotachography against the possibility of sudden fetal loss.

She was taken to the intensive care unit due to the sudden decrease in oxygen saturation at the end of the 21st hour following hospitalization. Consciousness was determined as confused, Glasgow coma scale: $14, \mathrm{sPO}_{2}$ $60 \%$ (under $10 \mathrm{lt} / \mathrm{min}$ oxygen), respiratory frequency $45 / \mathrm{min}$, blood pressure $110 / 70 \mathrm{mmHg}$, pulse $130 / \mathrm{min}$, diuresis $100 \mathrm{cc} /$ hour oxygen within minutes. As the saturation decreased to $60 \%$ and the respiratory rate was 24 per minute, the decision of intubation was made and the patient was transferred to a multidisciplinary hospital with a tertiary intensive care unit (ICU). Lopinavir $200 \mathrm{mg} /$ ritonavir $50 \mathrm{mg}$ (Kaletra $\left.{ }^{\circledR}\right) 200 \mathrm{mg}$ twice daily p.o. was added to the treatment. $\mathrm{FiO}_{2}$ of the intubated patient was $100 \%$, PEEP 10, VT $480 \mathrm{ml}$, respiratory frequency $20 / \mathrm{min}, \mathrm{sPO}_{2} 85 \%$. Emergency caesarean section was performed for the patient due to fetal distress 1 hour after intubation. 1100 gram baby girl was delivered. The baby was resuscitated by the neonatal team when the APGAR score was 0 in the first minute. The newborn whose saturation gradually reached the target value was transferred to our hospital's neonatal intensive care unit (NICU). In the patient who did not develop peroperative and postoperative obstetric complications, postoperatively Kaletra ${ }^{\circledR}$ treatment was discontinued and favipiravir $\left(\right.$ Avigan $\left.^{\circledR}\right) 2 \times 1600 \mathrm{mg}$ loading
$+2 \times 600 \mathrm{mg}$ maintenance po, methylprednisolone (Prednol ${ }^{\circledR}$ ) $40 \mathrm{mg}$ IV and enoxaparin sodium (Clexane ${ }^{\circledR}$ ) 6000 anti-Xa IU subcutaneous once a day started. The APACHE score of the patient was 25 and the expected mortality rate was $53.3 \%$.

The patient, who was evaluated as maternal ARDS with clinical, radiological, laboratory and blood gas parameters, was transferred to the 3 rd level adult intensive care unit of a multidisciplinary hospital after cesarean section. Here, her treatment was reorganized by adding linezolid (Linezone ${ }^{\circledR}$ ) $600 \mathrm{mg}$ twice a day to the patient's current treatment. It was learned that the PCR test result obtained in our hospital was positive. Despite all supportive treatments and maximal ventilator support, the patient developed cardiopulmonary arrest on the 4th postoperative day, and cardiopulmonary resuscitation (CPR) was performed for 40 minutes, but the patient did not respond to CPR, and thus, was accepted as exitus. The newborn, whose SARS-CoV-2 qRT-PCR analysis was negative, unfortunately was also accepted as exitus on the postpartum 3rd day, due to prematurity and acute respiratory distress syndrome.

\section{Discussion}

Although we have limited information about COVID19 during pregnancy, this infection has been associated with maternal complications such as premature rupture of membranes, preterm labor, preeclampsia, gestational diabetes, hypertension, and neonatal complications such as asphyxia and perinatal death. ${ }^{[6]}$ In addition, it has been reported in some publications that cesarean delivery rates in pregnancies complicated by SARS $\mathrm{CoV}-2$ infection are increased compared to the general population. ${ }^{[7]}$

Mortality rates vary by country and the severity of the disease in COVID-19 case series. While Lumbreras-Marquez et al. reported a $2.3 \%$ case fatality rate in pregnant women with COVID-19 in Mexico ${ }^{[8]}$ in a study from Iran, maternal death was reported in 7 of 9 pregnant women with severe COVID-19 infection. ${ }^{[9]}$ In a systematic review and meta-analysis including 11,580 pregnant women with confirmed or suspected COVID-19 diagnosis, pneumonia developed in $49 \%$, severe disease in $13 \%$, admission to adult intensive care unit in $4 \%$, invasive ventilation in $3 \%, 0.8 \%$ extracorporeal membrane oxy- 
genation (ECMO) has been reported. ${ }^{[10]}$ In this metaanalysis, maternal mortality rate was reported as $0.6 \%$. While most infected mothers ( $>90 \%)$ recover before delivery; ${ }^{[10]}$ rapid multiorgan failure and consequently maternal death can be seen in a small number of pregnant women. ${ }^{[11]}$ It has been reported that preterm birth rates are higher in pregnant women with COVID-19 compared to pregnant women without COVID-19 infection. ${ }^{[10]}$

In our country, according to the current data of the Ministry of Health, the mortality rate in pregnant women infected with SARS-CoV 2 was reported as $2.63 \% .^{[12]}$

Although we have limited information about COVID-19 during pregnancy, this infection has been associated with maternal complications such as premature rupture of membranes, preterm labor, preeclampsia, gestational diabetes, hypertension, and neonatal complications such as asphyxia and perinatal death. ${ }^{[6,13]}$ While pregnancy and childbirth often do not increase the risk of being infected with SARS-CoV-2, pregnancy may worsen the clinical course of COVID-19 compared to non-pregnant individuals of the same age. The presence of diabetes mellitus during pregnancy, chronic hypertension, increased body mass index, and being older than 35 years have been associated with severe COVID-19 infection. ${ }^{[10]}$

Nowadays, routine thoracic CT scan is not performed for the diagnosis of COVID-19 in pregnant women before hospitalization. However, CT scanning is recommended for symptomatic patients who are hospitalized in the presence of clinical indications. As a matter of fact, our case would have had a chance to survive with early diagnosis and treatment had she not refused thoracic CT and treatment.

Currently, there is no specific treatment or coronavirus-specific vaccine for COVID-19 with proven safety and efficacy. ${ }^{[14]}$ The use of treatment options based on data from randomized controlled trials appears to be safer. However, due to the urgency of our situation and the limited scientific data, some drugs such as hydroxychloroquine were used for the coronavirus, especially at the beginning of the pandemic. As can be seen in our report, we used hydroxychloroquine sulfate and lopinavir / ritonavir combination in our case initially for treatment purposes. The data we obtained from previous SARS and influenza infections suggested that early initiation of antiviral therapy is more beneficial. However, as months have passed since the outbreak, data from randomized trials have shown no benefit with either hydroxychloroquine or chloroquine administration. ${ }^{[15]}$ Moreover, it has been shown that this drug caused maternal cardiac side effects (such as QT prolongation). ${ }^{[15]}$ Thus, hydroxychloroquine has now been removed from our national COVID-19 treatment guide prepared by our Ministry of Health.

Since most trials of COVID-19 treatment exclude pregnant women, the clinical uses of some drugs remained for research purposes. These include remdesivir, systemic steroids, and plasma ${ }^{[16]}$ However, in the United States, two studies at the University of Pennsylvania are currently investigating the effects of plasma in pregnant women diagnosed with COVID19. ${ }^{[15]}$ We did not have a chance to use remdesivir in the pregnant woman in our case, because at that time it was not available in our country. However, Remdesivir has been available in our country since the last month, and is used by COVID-19 patients. We think that early treatment is effective in preventing the progression of the disease and maternal loss. Since favipiravir could not be used in pregnant women, favipiravir could only be started in the postoperative period in our case. However, in the postoperative period when the disease entered irreversible cascade, favipiravir was insufficient to provide the healing effect. In addition, we think that anticoagulant treatment was started on time and at an effective dose for steroid treatment and thromboembolism prophylaxis in our case.

\section{Conclusion}

While this case highlights the clinical course of COVID19 infection in a pregnant woman, the importance of early diagnosis and treatment, and the risk of feto-maternal loss in delayed diagnosis and treatment; it emphasizes that treatment approaches may change during the epidemic process and the importance of updating.

Funding: This work did not receive any specific grant from funding agencies in the public, commercial, or not-for-profit sectors.

Compliance with Ethical Standards: The authors stated that the standards regarding research and publication ethics, the Personal Data Protection Law and the copyright regulations applicable to intellectual and artistic works are complied with and there is no conflict of interest. 


\section{References}

1. Huang C, Wang Y, Li X, Ren L, Zhao J, Hu Y, et al. Clinical features of patients infected with 2019 novel coronavirus in Wuhan, China. Lancet 2020;395(10223):497-506. [PubMed] [CrossRef]

2. Zhang L, Jiang Y, Wei M, Cheng BH, Zhou XC, Li J, et al. Analysis of the pregnancy outcomes in pregnant women with COVID-19 in Hubei Province. [Article in Chinese] Zhonghua Fu Chan Ke Za Zhi 2020;55:166-71. [PubMed] [CrossRef]

3. Angus DC, Derde L, Al-Beidh F, Annane D, Arabi Y, Beane A, et al.; Writing Committee for the REMAP-CAP Investigators. Effect of hydrocortisone on mortality and organ support in patients with severe COVID-19: the REMAP-CAP COVID-19 corticosteroid domain randomized clinical trial. JAMA 2020;324:1317-29. [PubMed] [CrossRef]

4. Akhtar H, Patel C, Abuelgasim E, Harky A. COVID-19 (SARSCoV-2) infection in pregnancy: a systematic review. Gynecol Obstet Invest 2020;85:295-306. [PubMed] [CrossRef]

5. Ellington S, Strid P, Tong VT, Woodworth K, Galang RR, Zambrano LD, et al. Characteristics of women of reproductive age with laboratory-confirmed SARS-CoV-2 infection by pregnancy status - United States, January 22-June 7, 2020. Morb Mortal Wkly Rep 2020;69:769-75. [PubMed] [CrossRef]

6. Buonsenso D, Raffaelli F, Tamburrini E, Biasucci DG, Salvi S, Smargiassi A, et al. Clinical role of lung ultrasound for diagnosis and monitoring of COVID-19 pneumonia in pregnant women. Ultrasound Obstet Gynecol 2020;56:106-9. [PubMed] [CrossRef]

7. Chen H, Guo J, Wang C, Luo F, Yu X, Zhang W, et al. Clinical characteristics and intrauterine vertical transmission potential of COVID-19 infection in nine pregnant women: a retrospective review of medical records. Lancet 2020;395(10226): 809-15. [PubMed] [CrossRef]

8. Lumbreras-Marquez MI, Campos-Zamora M, Lizaola-Diaz de Leon H, Farber MK. Maternal mortality from COVID-19 in Mexico. Int J Gynaecol Obstet 2020;150:266-7. [PubMed] [CrossRef]

9. Hantoushzadeh S, Shamshirsaz AA, Aleyasin A, Seferovic MD, Aski SK, Arian SE, et al. Maternal death due to COVID-19. Am J Obstet Gynecol 2020;223:109.e1-109.e16. [PubMed] [CrossRef]

10. Allotey J, Stallings E, Bonet M, Yap M, Chatterjee S, Kew T, et al. Clinical manifestations, risk factors, and maternal and perinatal outcomes of coronavirus disease 2019 in pregnancy: living systematic review and meta-analysis. BMJ 2020;370:m3320. [PubMed] [CrossRef]

11. Chen Y, Li Z, Zhang YY, Zhao WH, Yu ZY. Maternal health care management during the outbreak of coronavirus disease 2019. J Med Virol 2020;92:731-9. [PubMed] [CrossRef]

12. Oncel MY, Akın IM, Kanburoglu MK, Tayman C, Coskun S, Narter F, et al.; Neo-Covid Study Group. A multicenter study on epidemiological and clinical characteristics of 125 newborns born to women infected with COVID-19 by Turkish Neonatal Society. Eur J Pediatr 2021;180:733-42. [PubMed] [CrossRef]

13. Liu W, Wang J, Li W, Zhou Z, Liu S, Rong Z. Clinical characteristics of 19 neonates born to mothers with COVID-19. Front Med 2020;14:193-198. [PubMed] [CrossRef]

14. Rasmussen SA, Smulian JC, Lednicky JA, Wen TS, Jamieson DJ. Coronavirus disease 2019 (COVID-19) and pregnancy: what obstetricians need to know. Am J Obstet Gynecol 2020; 222:415-26. [PubMed] [CrossRef]

15. Berghella V, Hughes B. COVID-19: Pregnancy issues and antenatal care. In: UpToDate, Post TW (Ed), UpToDate, Waltham, MA. (Accessed on June 2021)

16. Wang M, Cao R, Zhang L, Yang X, Liu J, Xu M, et al. Remdesivir and chloroquine effectively inhibit the recently emerged novel coronavirus (2019-nCoV) in vitro. Cell Res 2020; 30:269-71. [PubMed] [CrossRef]

This work is licensed under the Creative Commons Attribution-NonCommercial-NoDerivs 4.0 Unported (CC BY-NC-ND4.0) License. To view a copy of this license, visit http://creativecommons.org/licenses/by-nc-nd/4.0/ or send a letter to Creative Commons, PO Box 1866, Mountain View, CA 94042, USA.

Publisher's Note: The content of this publication does not necessarily reflect the views or policies of the publisher, nor does any mention of trade names, commercial products, or organizations imply endorsement by the publisher. Scientific and legal responsibilities of published manuscript belong to their author(s). The publisher remains neutral with regard to jurisdictional claims in published maps and institutional affiliations. 